[8] Vlasyuk, A., Zhukovskyy, V. (2017). Mathematical and computer modeling of intraparticle radionuclides mass transfer in catalytic porous media under isothermal conditions. Mathematical Modeling and Computing, 4 (2), 117-125. doi: http://doi.org/10.23939/mmc2017.02.117

[9] Kundas, S. P., Gishkelyuk, I. A., Grinchik, N. N. (2008). Chislennoe modelirovanie migratsii primesey v pochve. Prirodopol'zovanie i okruzhayushhaya sreda. Minsk: BelNITS «Ekologiya», 56-60.

[10] Vergunov, V. A., Vergunova, I. N., Oncsik, M. B., Dombovary, J. (2000). ${ }^{137}$ Cs Felhasznalasa masodlagos radioactiv szennyezod-desu Ukran, erdossztyeppes videk erozios folyamatainak vizsgalatara. Fizikai szemle, 7, 229-231.

[11] Brovka, G. P., Dorozhok, I. N., Ivanov, S. N. (2010). Raschetnye skhemy protsessov konvektivno-diffuzionnogo perenosa vodorastvorimykh soedineniy. Inzhenerno-fizicheskiy zhurnal, 83 (5), 866-872.

[12] Patil, S. B., Chore, H. S. (2014). Contaminant transport through porous media: An overview of experimental and numerical studies. Advances in Environmental Research, 3 (1), 45-69. doi: http://doi.org/ 10.12989/aer.2014.3.1.045

[13] Zhang, Y., Wang, Q., Zhang, S. T. (2011). Numerical Simulation of Benzene in Soil Contaminant Transport by Finite Difference Method. Advanced Materials Research, 414, 156-160. doi: http:// doi.org/10.4028/www.scientific.net/amr.414.156

[14] Vergunova, I. (2016). Multigrids method for numerical solution of equation of mass transfer in the system of hydrotechnical ramparts-terraces. Problems of decision making under uncertainties" (PDMU2016). Brno, 121-122.

[15] Vergunov, V. A., Vergunova, I. N. (2007). Modelling of masstransfer processes of polluted substance in the complex area with the systems of hydro-technical ramparts. In Proc. of the I International conf. of environmental science and water management. Szarvas, 7, 747-755.

\title{
APPLICATION OF INFORMATION TECHNOLOGIES FOR MANAGEMENT OF LOGISTIC FLOWS
}

\author{
Olga Kravchenko \\ Department of Information Technology Design \\ Cherkasy State Technological University \\ 460 Shevchenka blvd., Cherkasy, Ukraine, 18006 \\ kravchenko_ov@ukr.net \\ Elena Danchenko \\ Department of Business Administration and Project Management \\ University of Economics and Law "KROK" \\ 30-32 Tabirna str., Kyiv, Ukraine, 03113 \\ elenadan@krok.edu.ua \\ Sergii Martynenko \\ Department of Radio Engineering, Telecommunication and robotic systems \\ Cherkasy State Technological University \\ 460 Shevchenka blvd., Cherkasy,Ukraine, 18006 \\ smartynenko@ukr.net
}

\footnotetext{
Abstract

The process of managing logistics flows is one of the main factors influencing the increase of economic efficiency of production and sales.

The development of logistics information systems is a broad niche in the IT field. Application of logistic information systems in the process of management allows you to save money both on wages by the number of employees, and to accelerate the management process in a time interval.
} 
Ukraine is the leading country for grain exports. Issues of grain transportation management are considered as an alternative to manual control.

The article will discuss issues related to the application of the designed information system "Logistics transportation" to develop an optimal plan for transportation of grain, which clarifies existing models of logistics flows management.

To solve the problem, the authors analyzed the existing methods of managing logistic flows: direct methods (northwest method, least cost method, potential method) and methods based on additional calculations. A mathematical model of the problem of logistic flow management is constructed. The initiation solution is executed on the basis of the potentials method with additional conditions implemented in the network representation. The advantage of the used method is that the resulting reference plan is close to optimal computing. Although direct methods get the initial reference plan very quickly, but it is far from optimal. The clarification of the solution of the problem occurs through a block of logical rules.

Practical verification of data is carried out on the example of Agrarian firm "Zernotreyd". During the verification, it was found that the chosen management method leads to an increase in efficiency by $4 \%$.

Keywords: logistics flows, management, automated system, Information Technology.

DOI: $10.21303 / 2461-4262.2018 .00719$

(C) Olga Kravchenko, Elena Danchenko, Sergii Martynenko

\section{Introduction}

Agro-logistics is an actual topic for research, as Ukraine is among the top ten largest grain producers in the world and among the top three grain exporters [1].

Therefore, inefficiencies in the organization of logistics delivery routes and additional costs for it are becoming an increasingly important factor for Ukrainian grain producers. This undermines their competitiveness on the world market, especially against the backdrop of recent trends in falling global grain prices. Because the underperforming revenues force producers to reduce their investment in better crop production needed to survive on the market [2].

For the last 2015-2017, the most relevant area of research is the problems of transport logistics. In article [3] "Optimization of the state activity of the enterprise", ways of improving the company's work with the use of the logistic approach, introduction of the latest technologies and information systems for rational allocation of stocks are proposed.

The system of statistical processing of logistic information, intended for operational efficiency increase of business and development of logistic support of sales, is considered in work [4].

The importance of information provision in logistics is justified in the work [5]. This article discloses importance of information support in logistics. In article the basic concepts of information logistics, the feature of creation and functioning of information system providing functioning of logistic processes are considered [5].

In article [6] a method is suggest in which a firm might design and operate its LIS in light of the preceding expectations. A conceptual model of a JIT-LIS is presented, as well as specific suggestions for the implementation of the model in the automotive industry.

Analysis and study needs to develop information systems that are exploring a number of programs for the logistics market conduct authors of the article [7]. The logistics pipeline has become global in character and has become more complex too. Success in such a logistics network, as demonstrated by leading edge companies, involves close co-ordination across various functions, countries and cultures. Experts have predicted the widespread use of logistics information systems. Framework for an international logistics information system (ILIS) for a global company is suggested in [7].

The article [8] addresses issues closely related to the components of the logistics system: logistics services; information systems; infrastructure/resources. The analysis of logistic processes implemented in individual companies and the role of information flows in logistics processes are considered by the authors of the article [9].

Scientists' works [10-12] reveal many issues of the field of information transport logistics. However, insufficient attention is paid to the issue of improving logistics information systems, starting with elements of tracking operational requirements of customers. Operational requirements are distributed through distribution and production to suppliers. Not enough works are devoted to the logistics of cereals, which is an urgent problem for Ukraine. 
The relevance of selected topics allows to formulate a strategy aimed at creating efficiently functioning logistics systems that provide high quality customer service at low cost, which promotes the promotion of Ukrainian goods to foreign markets. The problem of grain logistics in Ukraine is the cost and speed of logistics exports of grain. Therefore, the question arose about improving the method of managing logistics flows. The developed automated system "Logistics transportation" practically implements this method. Data verification was carried out on an example of a conditionally created agricultural enterprise.

\section{The aim and objectives of the research}

The aim of research is the process of improving the method of managing logistics flows. The design and practical implementation of the automated information system "Logistics transportation" on its basis will allow optimizing freight costs and accounting for grain in warehouses.

The object of research is an agrarian enterprise, which exports products to different parts of the country and beyond. The creation of automated information system "Logistics transportation" will help solve the problem of logistics, namely, to find the optimal way of transportation of the product, which will lead to overcoming the barrier for the growth of grain exports.

To achieve this goal it is necessary to:

- construct a mathematical model of the problem of managing logistic flows;

- describe the program implementation of the Automated Information System "Logistics Transportation", which implements the search for an optimal solution;

- verify the data.

\section{Analysis of existing methods for managing logistics flows}

Methods of searching for initial support plans for the task of managing logistic flows can be divided into two groups: direct methods and methods based on additional calculations [13].

The group of direct methods contains a method of northwest angle, the least cost method (tariff) and their modification. The second group includes Vogel method, Lebedev method and others.

When using direct methods, the initial reference plan is obtained very quickly. However, such reference plan may be far from optimal. Finding the initial support plan by the second group method involves performing significant additional calculations, but the received reference plan is close to optimal. What is the best way to solve the problem of managing logistics flows is unknown [14].

\section{Results and discussion}

Let's solve the problem for a conditional enterprise operating in the Cherkasy region. To simulate the problem of logistic transportation, 7 farms located in Cherkassy oblast, namely Boyevshchyna, Zolotonosha, Stepanky, Berezniaky, Lebedin, Stetsivka, Khrystynivka and 6 grain storage facilities, were taken. Let's prepare a plan for grain transportation, which is located in 7 farms to 6 grain storage facilities of the enterprise with a partial permanent outflow of grain from 6 grain storage facilities to the Odessa port plant (OPP). The optimal plan for transportation of grain will be made, based on the minimum cost of transportation.

In Fig. 1, the task is presented as a network where:

$\mathrm{a}_{\mathrm{i}}$ is a farm with a volume of grown grain;

$\mathrm{b}_{\mathrm{j}}$ is a grain storage facility with a grain content;

$\mathrm{c}_{1}$ is the end point of transportation (OPP).

The Target Cost Function should go to the minimum values that ensure cost-effectiveness (1)-(5). The price includes the number of walkers, including those who are empty, which also affects the total mileage, salary and fuel. A certain amount of grain tone affects the number of walkers. 


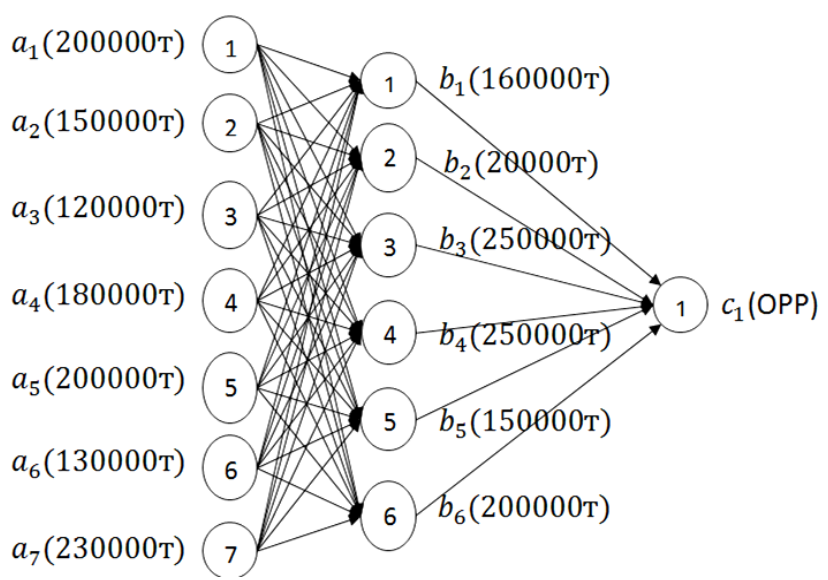

Fig. 1. Introduction of the task of managing logistic flows in the form of a network

The mathematical model of the problem is described in the form (1) under conditions (2)-(5).

$$
\begin{gathered}
L=\sum_{i=1}^{m} \sum_{j=1}^{n} c_{i j} x_{i j} \rightarrow \min , \\
\sum_{i=1}^{m} a_{i}<\sum_{j=1}^{n} b_{j}, \\
\sum_{j=1}^{n} x_{i j}=a_{i} ; \\
\sum_{i=1}^{m} x_{i j} \leq b_{j} ; \\
x_{i j} \geq 0, \quad(i=\overline{1, m}, j=\overline{1, n}), \quad(m, n \in Z) .
\end{gathered}
$$

This task refers to open-ended tasks. For the problem, the considered total demand exceeds the supply of suppliers. This is due to world grain market trends and climatic conditions.

In order to solve this problem, it is necessary to introduce fictitious $(m+1)$ - supplier of product storage modules:

$$
a_{m+1}=\sum_{j=1}^{n} b_{j}-\sum_{i=1}^{m} a_{i} .
$$

The cost of transportation (tariffs) of a unit of product for a fictitious supplier or consumer is considered equal to or greater than the largest of all transport tariffs. Tariffs are considered to be zero. In the target function fictitious supplier or consumer is not taken into account.

The classical methods of solving problems of this type are: the method of the north-west corner, the method of least cost, the method of potentials. Also, alternative alternatives and degeneracy should be considered.

Based on classical methods, a software product for managing logistics flows was developed. The basic principle is the improved application of the potential method. But when switching from a mathematical model of an open-type problem to a closed-ended problem, we suggest introducing an additional charging function $\mathrm{f}\left(\mathrm{x}_{\mathrm{ij}}\right)(7)$.

$$
f\left(x_{i j}\right)=\frac{1}{2} \sum_{i}^{m} \sum_{j}^{n} K_{i j} X_{i j},
$$


where the coefficient $\mathrm{K}_{\mathrm{ij}}$ to be responsible for an additional unforeseen financial burden in the formation of logistic flows.

Fig. 2 shows the functional model of the program "Logistics transportation", which automates the process of managing logistics flows.

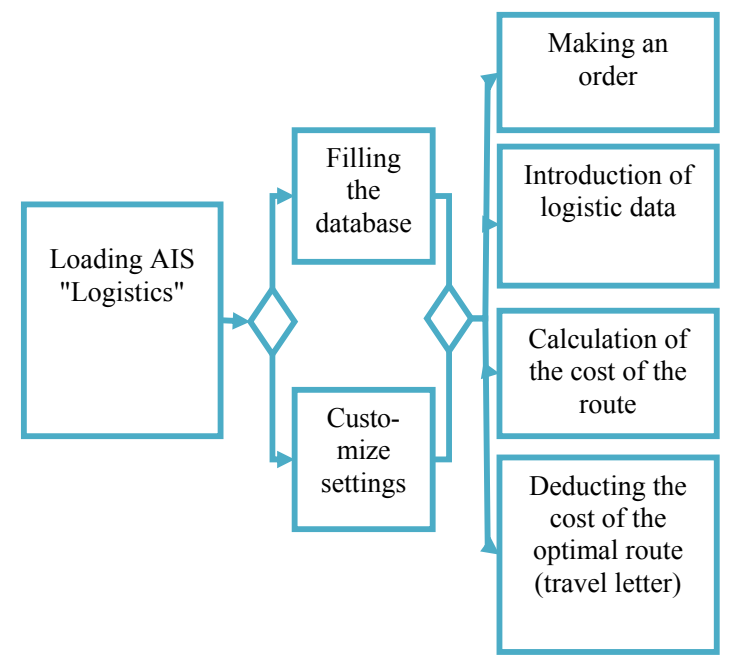

Fig. 2. Functional model of the program

Logistics data processing and the search for an optimal logistics flow plan are described in the general rule "If ..., then ...".

$$
\operatorname{IF}\left\{L \rightarrow \text { min, and } a_{i}<b_{j}, f\left(x_{i j}\right)\right\}, \operatorname{THEN}\left\{L\left(c_{k}\right) \text { with }\left(\sum_{i=1}^{m} \sum_{j=1}^{n} f\left(x_{i j}\right)+R(z)\right)\right\}
$$

where $a_{1} \ldots a_{n}$ is a farm with a volume of grown grain; $b_{1} \ldots b_{m}$ is a grain storage facility with a grain content; $f\left(x_{i j}\right)$ is the value of additional charging function according to expert data; $c_{k}-$ the end point of transportation; $\sum_{\mathrm{i}=1}^{\mathrm{m}} \sum_{\mathrm{j}=1}^{\mathrm{n}} \mathrm{f}\left(\mathrm{x}_{\mathrm{ij}}\right)$ - the total weight of the values of additional charging function according to expert data; $\mathrm{R}(\mathrm{z})$ - set of recommendations for logistics flow plan.

Fig. 3 shows an algorithm of AIS "Logistics transport" (Fig. 3). The algorithm contains six main steps.

The first step provides the filling of the data necessary for the calculations. This is a routine stage of human-machine interaction. In the future, with the mass implementation of this system, data will be obtained automatically from the accounts of farms and granaries.

The following steps are devoted to calculating optimal plans. Logical block of the system is used in the fourth step. Checking the resulting solutions provides an increase in the accuracy of the solution. Practical documentation is taking place at the sixth step. The formed documents are the basis for the company's accounting work.

The data verification was carried out to create a logistics flow of grain transportation, located in 7 farms in 6 grain storage facilities with a partial permanent outflow of grain to the Odessa port plant.

In accordance with the network of flows from Fig. 1, let's perform the calculation of the cost of transportation of grain between the nodes of the network by the formula:

$$
\mathrm{S}=\mathrm{S}_{1} \cdot\left(\mathrm{l}_{\mathrm{a}_{\mathrm{i}}} \cup \mathrm{l}_{\mathrm{b}_{\mathrm{j}}} \cup \mathrm{l}_{\mathrm{c}_{\mathrm{k}}}\right)+\mathrm{S}_{2}+\mathrm{S}_{3}
$$

where $1_{a_{i}}$ - the distance of transportation of grain from the site $a_{i} ; l_{b_{i}}$ - the distance of transportation of grain from the site $b_{j} ; l_{c_{k}}$ - the distance of transportation of grain from the site $c_{k} ; S_{1}-$ the price per $1 \mathrm{~km}$ of carriage according to the car's mark; $\mathrm{S}_{2}$ - the price per 1 ton of grain; $\mathrm{S}_{3}-$ cost resources to ensure the transportation process. 


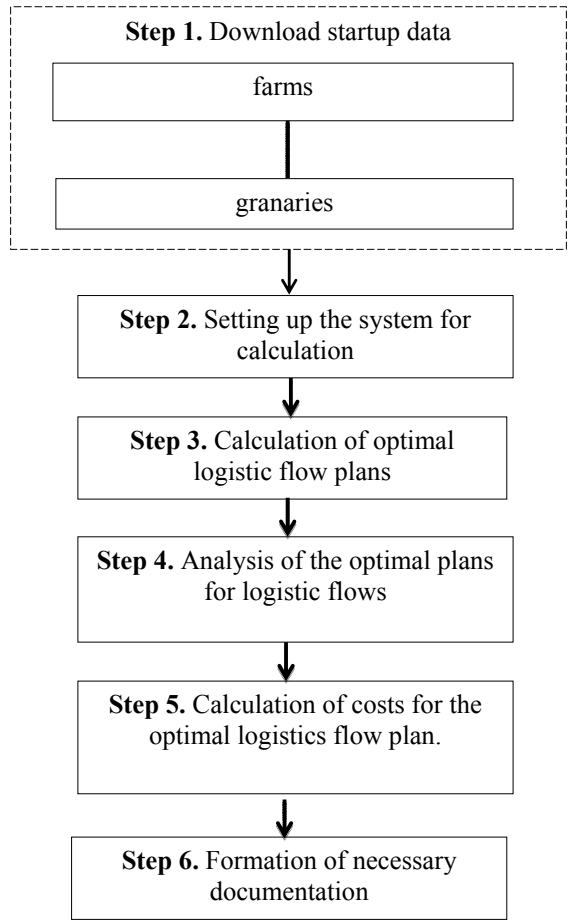

Fig. 3. Algorithm of AIS "Logistics transport"

The calculation was made for a price of $16 \mathrm{UAH}$ in $1 \mathrm{~km}$ distance and $3600 \mathrm{UAH}$ for 1 ton of grain.

The mathematical model of the problem will look like:

$$
\begin{gathered}
\mathrm{F}=3628 \mathrm{X}_{11}+4572 \mathrm{X}_{12}+5068 \mathrm{X}_{13}+5836 \mathrm{X}_{14}+7308 \mathrm{X}_{15}+9212 \mathrm{X}_{16}+ \\
+3772 \mathrm{X}_{21}+4092 \mathrm{X}_{22}+4540 \mathrm{X}_{23}+5308 \mathrm{X}_{24}+6668 \mathrm{X}_{25}+8044 \mathrm{X}_{26}+ \\
+5136 \mathrm{X}_{31}+3788 \mathrm{X}_{32}+3820 \mathrm{X}_{33}+4572 \mathrm{X}_{34}+5228 \mathrm{X}_{35}+6316 \mathrm{X}_{36}+ \\
+4492 \mathrm{X}_{41}+4204 \mathrm{X}_{42}+3740 \mathrm{X}_{43}+4492 \mathrm{X}_{44}+5132 \mathrm{X}_{45}+6236 \mathrm{X}_{46}+ \\
+5620 \mathrm{X}_{51}+4972 \mathrm{X}_{52}+4492 \mathrm{X}_{53}+3804 \mathrm{X}_{54}+4476 \mathrm{X}_{55}+5548 \mathrm{X}_{56}+ \\
+4940 \mathrm{X}_{61}+4636 \mathrm{X}_{62}+5068 \mathrm{X}_{63}+5836 \mathrm{X}_{64}+6476 \mathrm{X}_{65}+7740 \mathrm{X}_{66}+ \\
+8732 \mathrm{X}_{71}+6796 \mathrm{X}_{72}+6316 \mathrm{X}_{73}+5644 \mathrm{X}_{74}+5052 \mathrm{X}_{75}+3916 \mathrm{X}_{76}+ \\
+160000 \cdot 10236+200000 \cdot 9948+250000 \cdot 9532+250000 \cdot 10300+ \\
+150000 \cdot 9708+200000 \cdot 8716 \rightarrow \min ,
\end{gathered}
$$

where $\mathrm{x}_{\mathrm{ij}}$ - the volume of cargo transportation from the $\mathrm{i}$-th farm to the $\mathrm{j}$-th granary. Constraint system:

$$
\begin{gathered}
X_{11}+X_{12}+X_{13}+X_{14}+X_{15}+X_{16}=200000, X_{21}+X_{22}+X_{23}+X_{24}+X_{25}+X_{26}=150000 \\
X_{31}+X_{32}+X_{33}+X_{34}+X_{35}+X_{36}=120000, X_{41}+X_{42}+X_{43}+X_{44}+X_{45}+X_{46}=180000 \\
X_{51}+X_{52}+X_{53}+X_{54}+X_{55}+X_{56}=200000, X_{61}+X_{62}+X_{63}+X_{64}+X_{65}+X_{66}=130000 \\
X_{71}+X_{72}+X_{73}+X_{74}+X_{75}+X_{76}=230000, X_{11}+X_{21}+X_{31}+X_{41}+X_{51}+X_{61}+X_{71}=160000 \\
X_{12}+X_{22}+X_{32}+X_{42}+X_{52}+X_{62}+X_{72}=200000, X_{13}+X_{23}+X_{33}+X_{43}+X_{53}+X_{63}+X_{73}=250000 \\
X_{14}+X_{24}+X_{34}+X_{44}+X_{54}+X_{64}+X_{74}=250000, X_{15}+X_{25}+X_{35}+X_{45}+X_{55}+X_{65}+X_{75}=150000 \\
X_{16}+X_{26}+X_{36}+X_{46}+X_{56}+X_{66}+X_{76}=200000, X_{i j} \geq 0
\end{gathered}
$$


The optimal plan has the form (Table 1):

Table 1

Optimal plan of transportation

\begin{tabular}{|c|c|c|c|c|c|c|}
\hline $\mathrm{A}_{\mathrm{j}}$ & 160000 & 200000 & 250000 & 250000 & 150000 & 200000 \\
\hline 200000 & 160000 & 40000 & 0 & 0 & 0 & 0 \\
\hline 150000 & 0 & 150000 & 0 & 0 & 0 & 0 \\
\hline 120000 & 0 & 0 & 120000 & 0 & 0 & 0 \\
\hline 180000 & 0 & 0 & 130000 & 50000 & 0 & 0 \\
\hline 200000 & 0 & 0 & 0 & 200000 & 0 & 0 \\
\hline 130000 & 0 & 10000 & 0 & 0 & 120000 & 0 \\
\hline 230000 & 0 & 0 & 0 & 0 & 30000 & 200000 \\
\hline
\end{tabular}

Target function $\mathrm{F}=16848140200 \mathrm{UAH}$ (Fig. 4).

\begin{tabular}{llllll}
\hline$\square$ & & & \\
$\square$ & Bojovschuna & Nibylon SP, TOV & v.Drabove st.Nahimova 30 & 300 & $\boldsymbol{\nabla}$ \\
$\square$ & Zolotonosha & KHP, PrAT & t.Cherkassy pr.Himikiv 7 & 150 & $\boldsymbol{\nabla}$ \\
$\square$ & Stepanku & NZK, TOV & t.Smila st.Polova 4 & 120 & $\boldsymbol{\nabla}$ \\
$\square$ & Berezniki & LNZ, PAT & t.Shpola st.Zavodzka 17 & 180 & $\boldsymbol{\nabla}$ \\
$\square$ & Stesivka & KE, TOV & t. Erky, st. Lenina 47 & 200 & $\nabla$ \\
$\square$ & Stesivka & DPZKY & t.Uman st.Steritskogo 7 & 130 & $\nabla$ \\
$\square$ & Khrestinevka & DPZKY & t.Uman st.Steritskogo 7 & 230 & $\nabla$
\end{tabular}

Calculate the cost of the route

Costs

Total length of the route: $238232 \mathrm{~km}$

Wages of the driver $6 \mathrm{ua} / 1 \mathrm{~km}=9063655200 \mathrm{ua}$

Fuel costs $29 \mathrm{grn} / 10 \mathrm{~km}=71106555200$ ua

Total cost: 16174310400 ua

Transport: MAN 2365

Volume: $20 \mathrm{t}$

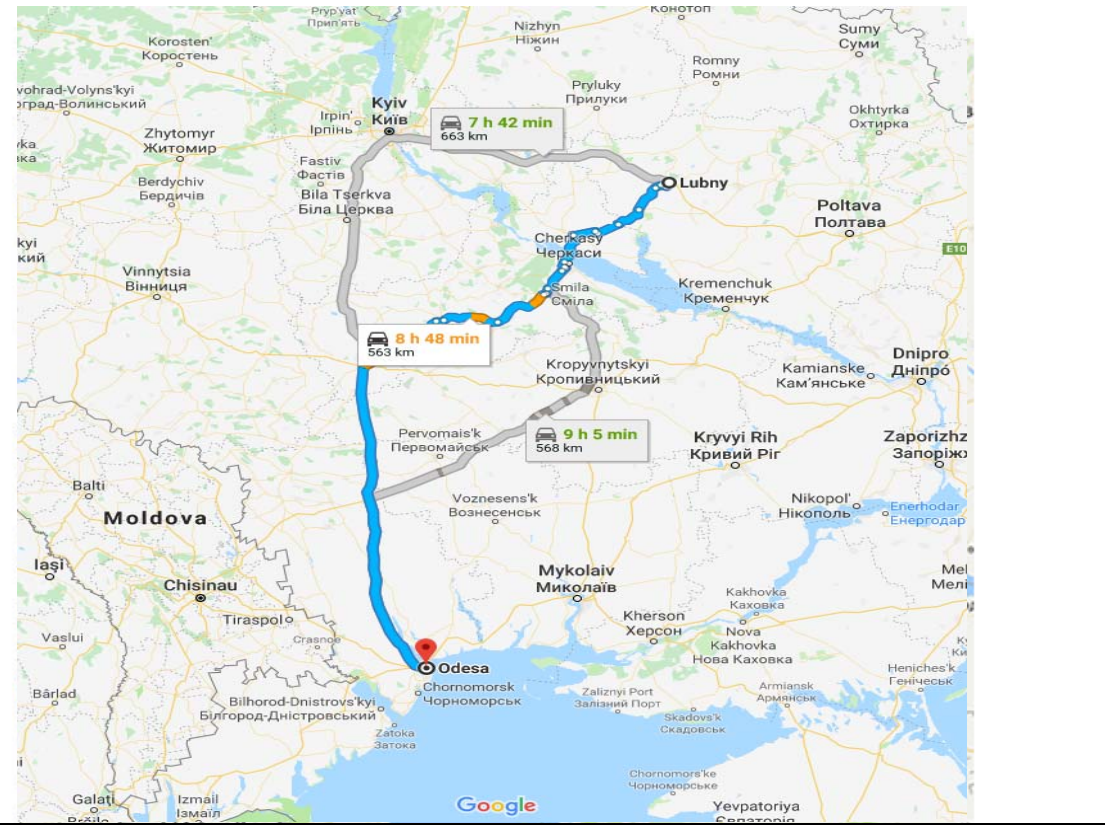

Fig. 4. Calculation of the cost of the route to the information system "Logistics transportation" 
The obtained results were verified for the stability of the solution. Let's conduct the verification on the basis of logical rules (8).

For comparison, the verification of the results of transport task solutions by means of traditional methods of research (using the least cost method, using Excel tools) was performed.

Fig. 5 shows a comparison of solving methods, where the numerical values on the left are the results of the search solution, and the values below represent the percentage of the accuracy of the solutions.

The solution to the AIS "Logistics transportation", which is the practical implementation of the improved method of managing logistics flows, was $4 \%$ more accurate in contrast to the manual solution and the solution by means of Excel (Fig. 5).

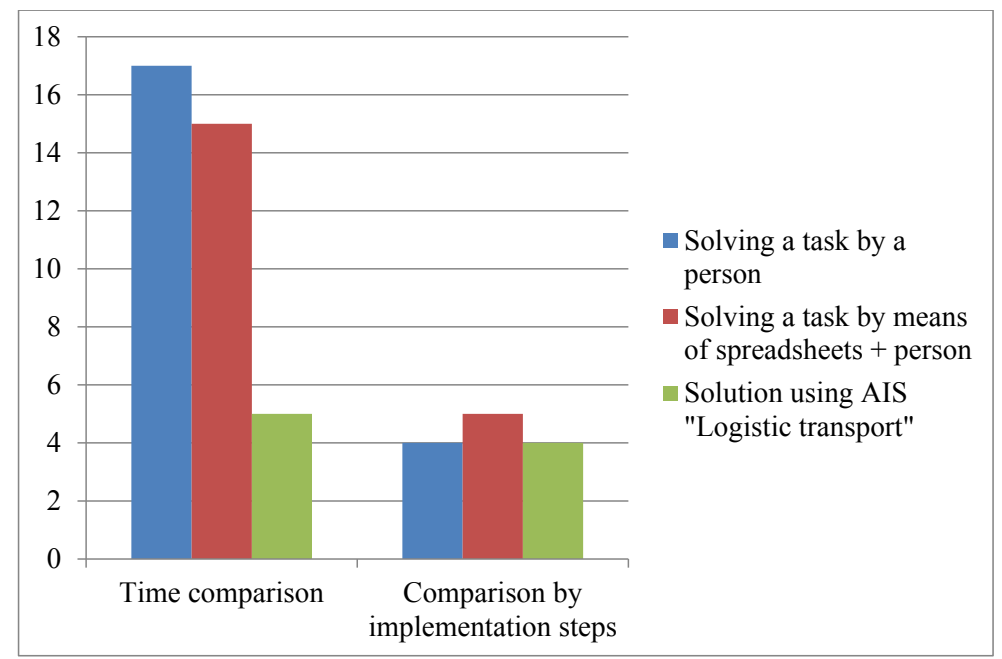

Fig. 5. Diagram of comparison of the accuracy of results by steps of the solution and time

A completed SWOT analysis of research results shows that:

- the strength of the information system is the presence in its structure of the module for the formation of recommendations for the decision on the correctness of the logistics flow. Having a database with rules in the form of "if ..., then ..." allows to reduce the response time of the system to the user's request. Another advantage is the price of a software product compared with existing analogues, which, when implemented, has to pay off in a few years;

- the disadvantage of the system created is the initial stage of its implementation, which requires manual filling of data that requires a training process for staff;

- in the future, this system allows to add the necessary module. Also, the system has the option of additional customization according to the requirements of the client.

1) Threats that could have a negative impact on the system include:

- insufficient funding for the procurement of the program;

- expenses for training of personnel;

- the need for the introduction of a specialist who will be responsible for the maintenance of the software product;

- initial cost of time when filling the database.

2) The developed software product takes into account the advantages of analogues in the logistics flow management market, but has lower cost and benefits in ease of use.

So, comparing the results of the solution of the problem, let's conclude that the most effective was the automated information system "Logistics transportation", because with its help the task of managing logistics flows.

\section{Conclusions}

The development and application of information provision for logistics management has a strong role in business and management of information flows and resources. 
The development of the automated information system "Logistics transportation" led to the savings of incoming resources.

It is based on an improved mathematical model of the task of managing logistics flows.

The use of logical rules such as "If ..., then ..." when designing the system allows to shorten the system response time to the user's request.

Practical verification of data is carried out on the example of agrarian firm "Zernotreyd". In the course of the verification it was established that the chosen method of managing logistics flows leads to an increase in efficiency by $4 \%$. The applied method allows obtaining the optimal plan close to the optimal computing with the implementation of minimization of the cost function. Work in the information system "Logistics" reduces the number of errors in the account; the amount of "paper" work decreases.

\section{References}

[1] Khristenko, G. (2016). Development of logistics of the grain market Sekciia: ekonomichni_nauki. Available at: http://econf.at.ua/publ/konferencija_2016_12_8_9/sekcija_5_ekonomichni_nauki/rozvitok_logistiki_zernovogo_rinku/61-1-0-1542

[2] Naumenko, D. (2016). Logistics of Cereals in Ukraine: Barriers to Export Growth. Available at: https://ukr.lb.ua/economics/2016/08/15/342521_logistika_zernovih_ukraini.html

[3] Pelenskyy, R. A. (2016). Optimization of ware-house activity of enterprise. Naukovyi visnyk Lvivskoho natsionalnoho universytetu veterynarnoi medytsyny ta biotekhnolohii imeni S. Z. Gzhytskoho, 14 (4 (54)), 427-432. Available at: elibrary.ru/item.asp?id=25610482

[4] Khayrullin, R. (2015). The system for statistical analysis of logistic information. Vestnik MGSU, 5, 133-140. doi: http://doi.org/10.22227/1997-0935.2015.5.133-140

[5] Songolov, A. Yu. (2016). Information provision in logistics. Aktual'nye problemy aviacii i kosmonavtiki, 2 (12), 1027-1029. Available at: elibrary.ru/item.asp?id=28146658

[6] Bookbinder, J. H., Dilts, D. (2016). Logistics Information Systems in a Just-in-Time Environment. Journal of Business Logistics, 10 (1), 1989. Available at: https://ssrn.com/abstract=2801731

[7] Bagchi, P. K. (1992). International Logistics Information Systems. International Journal of Physical Distribution \& Logistics Management, 22 (9), 11-19. doi: http://doi.org/10.1108/09600039210022952

[8] Sreenivas, M., Srinivas, T. The role of transportation in logistics chain. Available at: http:// appliedmathematician.org/journals/plagiary/1814.pdf

[9] Nowakowska-Grunt, J., Nowakowska, A. Selected tools of information flow management in logistics. Available at: https://www.ue.katowice.pl/fileadmin/_migrated/content_uploads/5_J.Nowakowska-Grunt_A.Nowakowska_Selected....pdf

[10] Logistics and Transportation (2016). Available at: https://managementmania.com/en/logisticsand-transportation

[11] Transportation, distribution and logistics (2018). Available at: https://canadabusiness.ca/managing-your-business/day-to-day-operations/supply-chain-management/transportation-distribution-and-logistics/

[12] Automated Logistics Systems (ALS) Case Study. Available at: https://www.tmwsystems.com/ case-studies-resources/case-studies/automated-logistics-systems-als-case-study

[13] Kuchma, M. I. (2006). Mathematical Programming: Examples and Tasks. Lviv: New World 2000,342 .

[14] Akulich, I. P. (2011). Mathematical programming in examples and tasks. Moscow: Lan, 352.

[15] Velichko, O. P. (2015). Logistics in the system of agrarian enterprises. Dnipropetrovsk: Accent of PE, 525.

[16] Kornienko, S. K. (2010). Automation logistics system. Radioelektronika, informatyka, upravlinnia, 2, 148-152. Available at: http://cyberleninka.ru/article/n/avtomatizirovannaya-logisticheskaya-sistema

[17] Smirnov, I. G., Kosareva, T. V. (2008). Transport logistics. Kyiv: Center for Educational Literature, 224 . 